the Soviet Union never to deploy in space any piece of equipment capable of destroying another (weapons of "mass destruction" are already banned)? The deployment of SDI components would be one of those rare and recognizably novel occasions in military affairs when something qualitatively novel is being attempted. Those who look for firebreaks in the arms race would be right to think that this is one. If, in the short run, the Soviet Union is compelled to regard President Reagan's attachment to SDI as a fact of life, may not Mr Mikhail Gorbachev, in the next round, require the United States to take his determination that SDI shall not prosper in the same spirit?

\section{Clandestine government}

\section{The US government needs an effective cabinet; British government should not gag its press.}

THERE is an odd parallel between the congressional investigation in the United States of the sale of arms to Iran (and the diversion of some of the funds collected) and the present fuss in Britain about the memoirs of Mr Peter Wright, a former agent of the British security services now living in Tasmania. But there are also glaring contrasts between the two affairs. The proceedings in Washington are remarkable for how much has been told of how public servants set about running clandestine operations of which the government which employs them was collectively ignorant.

In the British case, on the other hand, where one of Wright's revelations (in a book called Spycatcher) is that the intelligence services had set out in the 1970 s to discredit those to whom it.was responsible, the government has gone to extraordinary lengths to make sure that Wright's allegations, true or false, are not discussed. Last week, the government won a ruling from the legal committee of the House of Lords that the British press may not discuss the details of the allegations which are probably being given more publicity elsewhere than they deserve by the government's attempts to keep them quiet.

The lesson to be drawn from what has emerged in Washington is that the United States needs a device for making cabinet government function as it should. The tale is that a handful of people employed at the White House were able to carry out a clandestine operation without formal authority and without most members of the government knowing what was going on.

What the congressional committee has failed to do is to discover whether President Reagan knew what had been going on. None of the witnesses has implicated the president, but most have blamed the late director of the Central Intelligence Agency, William Casey, who died a few days after first giving private evidence to the committee, and who was a member of the cabinet. Two other cabinet members (the Secretaries of State and of Defense) said that what little they learned of the clandestine operation led them to protest, with the consequence that they were shut out from further discussions of the matter. That could not happen in Britain, where any member of the cabinet has a right to know what may be going on, and in return is required to support the collective view even if he does not like it - or to resign. On the second centenary of an otherwise admirable constitution, the congressional committee should look for ways of asserting collective cabinet responsibility in the United States.

In Britain, the doctrine works, if anything, too well. There is no reason to believe that the twenty-odd members of the cabinet all believe that de facto censorship of the British press on a particular matter is an appropriate price to pay for the pursuit of legal means for preventing discussions of the Wright book, especially because the effort will eventually be fruitless. The government's assertion that its objective is merely to prevent Wright from "lining his pockets" with profits from his book sounds like humbug; without the publicity from all the legal actions, it is unlikely that Wright would have earned an estima- ted $\$ 250,000$ in royalties during the first ten days of his book's publication in the United States. In this case the British cabinet would be better employed seeking ways of preventing future breaches of confidentiality by members of its intelligence services. Its lawyers, who are said to have spent $£ 1$ million already in their pursuit of Wright, would be better employed drafting watertight contracts with his successors. If, as seems possible, it is a problem that people wishing to spill the beans move outside their governments' jurisdiction (there are some recent cases in the United States as well as in Britain), is it improper to think of some form of extradition treaty between like-minded governments? Better that than censorship.

\section{Going for broke}

\section{The largest British research council is in a hurry to set up novel research centres. Will they succeed?}

THE British Advisory Board for the Research Councils (ABRC) has not had to wait long for a reaction to its suggestion that research councils should in future support academic research at British universities by setting up goal-oriented research centres near but not within universities. The scheme, first described only three weeks ago (see Nature 328, 280; 1987), and endorsed only cautiously by the government, seems to have been embraced enthusiastically by the largest of the research councils, that responsible for science and engineering (SERC). Now SERC says that it hopes to set up no fewer than seven of these centres, not to mention that on the science and engineering of superconductivity for which bids have already been invited (see Nature 328, 370; 1987, and page 464 in this issue). To the extent that these developments promise change in an otherwise stagnant setting, they are to be welcomed. But there is a case for asking that SERC will tread carefully in what it is about.

Even in Britain, university-based research centres are not unprecedented. The Medical Research Council (MRC) will, for example, quickly say that it has for more than 30 years been doing what SERC now plans, although a better analogy is the network of university research organizations founded over the past two decades by the Wolfson Foundation.

What SERC is now planning (with the collaboration of the Agricultural and Food Research Council in the case of a centre for process technology), are centres which are intrinsically interdisciplinary, but whose academic staff will include many from the host institution (polytechnics as well as universities are allowed) or institutions (consortium bids will be encouraged). There will also be research staff provided centrally, on longish but not permanent contracts, a director with "power" to change the research programme in the light of changing circumstances and a management committee to ensure that he or she has a programme. Industrial collaboration is talked of.

So far, so good. SERC's good intentions will not be questioned, but only the possibility that it may be trying to kill too many birds with the same stone. One objective is to shift the pattern of British research in directions that underpin industrial innovation, another is to encourage interdisciplinarity. That too makes sense. But the plan that the new centres should provide hospitality for visiting academics looks like an intended solution to quite a different problem, that of occupying the skills of able academics likely to be underoccupied except as teachers when the planned practice of selectivity begins to bite. SERC is plainly also ambivalent about the management of its centres. While warning academic institutions in its invitation for bids that some of the new ventures may fail, it plans to keep a hand in their management as if persuaded that it can help avoid that happening. Would it not be wiser to stand well aside? Seeing whether academic enterprises can sink or swim should be another part of what is a bold experiment - much bolder than that being mounted by the National Science Foundation in the United States. 